\title{
NEWS SECTION
}

\section{Composers}

Notes of premieres of new works run from three months before to three months following publication of this issue, i.e. from 1 July to 31 December. There is therefore a threemonth overlap between issues, and omissions and late news for the three 'following' months of the current issue will be picked up in the three 'prior' months of the next one. News of more distant forthcoming premières is given more briefly; full details will be found in subsequent issues.

LOUIS ANDRIESSEN La Girò (première) - 5 September Milan / Turin, Conservatory Hall / Monica Germino (vln), London Sinfonietta c. David Atherton.

JOANNA BAILIE Tuning (première) - 19 September London, Queen Elizabeth Hall/Simon Wall (ten), Endymion, EXAUDI, c. James Weeks.

RICHARD BARRETT CONSTRUCTION for 3 vocalists, 16 instrumentalists, electronics and installation (première) - 19 November Huddersfield Festival / ELISION.

LUKE BEDFORD String Quartet (première) 30 December London, Wigmore Hall / The Heath Quartet.

HARRISON BIRTWISTLE Divisions (première) - 5 September Milan/Turin, Conservatory Hall / Monica Germino (vln), London Sinfonietta c. David Atherton.

RICHARD BLACKFORD Not In Our Time (première) 11 September Cheltenham, Town Hall/Bourmemouth Symphony Orchestra \& Chorus c. Gavin Carr.

JOHN CASKEN The Knight's Stone (première) - 23 July Alwinton, Alwinton Church/Gavin Osborn (fl), Northern Sinfonia Chorus c. Alan Fearon.

ENRICO CHAPELA Magnetar (première) - 20 October L.A., Walt Disney Hall/Johannes Moser (elec.vlc), Los Angeles Philharmonic c. Gustavo Dudamel.

ELENA KATS-CHERNIN Obsidian Light (première) 11 August Hobart, federation Concert Hall / Tasmanian Symphony Orchestra c. Alexander Mickelthwate.AlexanderRag (première)-28 October Queensland, Ferry Road Studios/Richard Pollett (vln), Oliver She (pno), Queensland Symphony Orchestra c. Paul Fitzsimon.
JOHN CORIGLIANO One Sweet Morning (première) - 30 September NY, New York/Stephanie Blythe, New York Philharmonic c. Alan Gilbert.

LAURENCE CRANE Piano Quintet (première) 16 October London, Queen Elizabeth Hall / Andrew Matthews-Owen (pno), the Brodowski Quartet. A Cabaret Festschrift (see TANSY DAVIES).

SEBASTIAN CURRIER Traces (US première) - 22 July Jackson Hole, WY, Walk Festival Hall/Naoko Yoshino, (hp), Grand Teton Music Festival c. Osmo Vanska

TANSY DAVIES A Cabaret Festschrift with Laurence Crane, Robert Fokkens \& Dougal Irvine (première) - 16 October London, Queen Elizabeth Hall / Claire Booth (sop) and Andrew Matthews-Owen (pno).

BRETT DEAN Fire Music (première) - 10 November Stockholm, Konserthuset/Royal Stockholm Philharmonic c. Sakari Oramo.

JAMES DILLON Oslo/Triptych (UK première) - 19 November Huddersfield Festival/Cikada Ensemble.

JOE DUDDELL Magnificat (première) - 23 July Bleddfa, Church of St. Mary Magdalene, Presteigne Festival/Choir of Royal Holloway, University of London c. Rupert Gough.

STEPHEN GOSS Portraits and Landscapes (première) 14 September London, Wigmore Hall / Emmanuel Despax (pno).

HELEN GRIME Luna (première) - 15 October Glasgow, McEwan Hall / Red Note Ensemble.

HK GRUBER Northwind Pictures (première)4 September Grafenegg Summer Music Festival / Niederösterreichisches Tonkünstlerorchester c. composer.

STEFAN HEUCKE Symphony No. 4 (Concertante for Orchestra), op. 59 (première) - 12 July Krefeld, Seidenweberhaus / Niederrheinische Sinfoniker.

ROBIN HOLLOWAY Gold on Bronze (première) 16 November London, Cadogan Hall/King's College School Wimbledon Symphony Orchestra c. Daniel Phillips.

TOSHIO HOSOKAWA Blossoming II (première) 21 August Edinburgh International Festival, 
Usher Hall / Scottish Chamber Orchestra c. Robin Ticciati. Etude 1: 2 Lines (première) - 26 August Bolzano, Claudio Monteverdi Conservatory of Music / Nicholas Hodges (pno).

PIERRE JALBERT Trio for violin, clarinet and piano - 27 November London, Wigmore Hall/Chamber Music Society of Lincoln Center.

KARL JENKINS For the Fallen (US première) 11 September New York, Lincoln Center/Distinguished Concerts Singers International, The Really Big Chorus c. Karl Jenkins.

CHRISTIAN JOST Der Zaubergarten (première) 14 July Ingolstadt Festival, AUDI Summer Concerts 2011 / Akademie für Alte Musik Berlin.

ANDERS KOPPEL Le Balajo (première) 29 July Denmark, Gjethuset, Frederiksvaek Kammermusikfestival / Copenhagen Cello Quartet.

GYÖRGY KURTÁG In Memoriam Pauline MaraIsserlis (première) - 23 July London, Wigmore Hall / Stephen Isserlis and friends.

BERNHARD LANG Tables are Turned (UK première) - 20 November Huddersfield Festival/Philip Jeck (turntables), Alter Ego.

THOMAS LARCHER Madhares (UK première); IXXU (UK première); Piano Quintet (première) - 12 November London, Wigmore Hall/ Quatuor Diotima, Mihaela Ursuleasa (pno), Belcea Quartet.

JOHN MCCABE Esperanza (première) - 7 July St Albans Abbey \& St. Saviour's Church. Horn Quintet (première) - 12 October Liverpool, St George's Concert Hall/David Pyatt (hn), Sacconi String Quartet.

ROLF MARTINSSON Suite Fantastique (première) 10 November London, Wigmore Hall / Martin Fröst (cl) and Roland Pöntinen (pno).

PETER MAXWELL DAVIES Kommilitonen! (Young Blood!) (US première) - 16 November New York, Juilliard School/Juilliard Schhool of Music c. Anne Manson.

ANDREW NORMAN Sonnets (première) - 12 August Aspen, Aspen Music Festival and Summer School, Benedict Music Tent/ Aspen Chamber Symphony c. Hugh Wolff.

TARIK O’REGAN Acallam na Senorach (première) - 13 October Indiana, University of Notre Dame/National Chamber Choir of Ireland c. Paul Hillier.

EINOJUHANI RAUTAVAARA Missa a cappella (première) - 25 November Utrecht, Jacobikerk/Netherlands Radio Choir c. Celso Antunes.
ARIBERT REIMANn Rilke-Fragment - 12 August Bad Kissingen, Regentenbau, Rossini-Saal Kissinger Sommer 2011/Caroline Melzer (sop), Axel Bauni (pno).

AULIS SALLINEN Concerto for Cor Anglais and Chamber Orchestra (première) - 22 November Helsinki, Helsinki Concert Centre/Aale Lindgren (ca), Helsinki Filharmonia c. Okko Kamu.

ESA-PEKKA SALONEN Nyx (US première)-27 October Atlanta / Atlanta Syphony c. Esa-Pekka Salonen.

FAZIL SAY Sonata for Violin and Piano (UK première) 29 July London, Wigmore Hall / Priya Mitchell (vln), Natacha Kudritskaya (pno). Khayyam (première) - 16 July Kiel / Sabine Meyer (cl), Bilkent Symphony Orchestra c. Isin Metin. Variationem (première) - 4 August Flensburg, Deutsches Haus, / Ferhan and Ferzan Önder (pno), Martin Grubinger (perc). Vier Lieder (première) - 14 August Pronstorf, Kuhstall / Annelie Sophie Müller (sop), Elif ŞahinNeswada (pno). These three premières were all part of the Schleswig-Holstein Music Festival 2011.

ENJOTT SCHNEIDER Salaam (première) - 10 July Augsburg, Rathausplatz/Opernchor des Theater Augsburg, Philharminischer Chor Augsburg and others.

JOHANNES SCHÖLLHORN Contrapunctus VI, IV, IX, XI and canon per augmentationem in contrario motu 3 (from Anamorphoses) (première) - 24 November London, Queen Elizabeth Hall/Unsuk Chin (presenter), players from the Philharmonia Orchestra c. Roland Kluttig.

KURT SCHWERTSIK Chalifa und die Affen (première) - 26 August Expedithalle der Brotfabrik, Vienna/Sirene Operntheater/PHACE contemporary music c. François-Pierre Descamps.

SEAN SHEPHERD Quartet for Oboe and Strings (première) - 11 August Santa Fe, NM / Liang Wang (ob), Orion String Quartet.

BENT SØRENSEN It is pain flowing down slowly on a white wall (première) - 10 September Oslo, Ultima Festival/Frode Halti (acc), Telemark Kammerorchester; (UK première) - 18 November Frode Halti (acc), Trondheim Soloists. Shadowplay for three trios (UK première) - 22 November Cikada and Scenatet Ensembles. Saudades Inocentes for singers, guitar, accordion and loudspeakers (UK première) 27 November Scenatet Ensemble. All UK premières as part of 2011 Huddersfield Contemporary Music Festival.

PĒTERIS VASKS Epifania (première) - 29 July Kokkola FIN/Ostrobothian Chamber Orchestra c. Juha Kangas. 
ROLF WALLIN Trumpet Concerto (première) - 29 September Cologne, Philharmonie/Håkan Hardenberger (tpt), WDR Symphony Orchestra, c. Jukka-Pekka Saraste.

HUW WATKINS Look Down, Fair Moon (première) 29 September London, Wigmore Hall/Gerald Finley (bar) and Julius Drake (pno). Concertino (première) - 30 August Presteigne, St. Andrew's Church, Presteigne Festival 2011/Tamsin WaleyCohen (vln), Presteigne Festival Orchestra c. George Vass.

JUDITH WEIR Miss Fortune (Achterbahn) (première) - 21 July Austria, Bregenzer Festspiele, Festspielhauis / Wiener Symphoniker c. Paul Daniel.
HANS ZENDER Oh bosques - $O$ Wälder (première) - 8 July Munich, Herkulessaal/Bavarian Radio Symphony Orchestra and Choir c. Susanna Mälkki. Logos-Fragmente VII und VIII (première) - 28 July Heiligkreuz-Münster, Schwäbisch Gmünd/SWR Choral Ensemble Stuttgart, SWR Symphony Orchestra of Baden-Baden and Freiburg c. Emilio Pomárico.

UDO ZIMMERMANN Wie kannst du ohne Hoffnung sein (première) - 8 July Munich, Herkulessal / Bavarian Radio Symphony Orchestra and choir c. Susanna Mälkki. 


\section{CONTRIBUTORS}

Tim Rutherford Johnson writes on contemporary music for the Guardian, INTO, Tempo and his blog, The Rambler. He is currently preparing the 6th edition of the Concise Oxford Dictionary of Music.

Katharina Clausius is a Doctoral Fellow in the Department of Music at Columbia University. Her research focuses on late eighteenth-century opera and early 20th-century modernism.

Robin Maconie has a new collection of essays Avant Garde: An American Odyssey in the pipeline, and is preparing a sequel to Other Planets covering the final works and legacy of Stockhausen.

Erling E. Guldbrandsen is professor at the Department of Musicology, University of Oslo since 2004 and is leader of the $\mathrm{PhD}$ programme in musicology, arts, and the history of ideas since 2006. From 1990 on he studied Boulez's music at IRCAM and at the Paul Sacher Foundation, Basle, and he delivered his Doctoral dissertation at the University of Oslo in 1995: Tradisjon og tradisjonsbrudd. En studie i Pierre Boulez: 'Pli selon pli - portrait de Mallarmé' [Tradition and Rupture in Post-War Modernism. A Study in Pierre Boulez's 'Pli selon pli-portrait de Mallarmé']. The thesis was awarded His Majesty the King's Gold Medal Prize in 1996. It was published at the Scandinavian University Press, 1997. Guldbrandsen has more recently published widely on Boulez, Wagner, Mahler, music history and aesthetics. The first three instalments of his interview with Pierre Boulez, which took place in 1986, have appeared in the January 2011, April 2011 and July issues of Tempo.

Paul Conway is a freelance writer and music critic, specializing in 20th-century and contemporary British music. He has reviewed for Tempo since 1997 and The Independent since 2000 and has provided sleevenotes for Lyrita, Dutton and Nimbus discs and programme notes for The Proms, Edinburgh and Spitalfields Festivals.

Alexander Ivashkin is a writer, cellist and conductor, Professor of Music and Director of the Centre for Russian Music at Goldsmiths, University of London. $\mathrm{He}$ has published books on Penderecki, Ives, Schnittke and Rostropovich, performed in more than 40 countries, and recorded the complete cello music by Rachmaninov, Prokofiev, Shostakovich, Schnittke, Roslavets, Alexander Tcherepnin, Kancheli, Gubaidulina, Korndorf and Smirnov for Chandos, Naxos and BMG.

Malcolm Miller, musicologist and pianist, is Associate Lecturer for the Open University in London, Associate Fellow of the Institute of Musical Research (School of Advanced Studies, University of London), tutor at the City Literary Institute and Director of the Forum for Israeli Music, Jewish Music Institute, SOAS (University of London). He received his doctorate from King's College, London, is editor of Arietta, Journal of the Beethoven Piano Society of Europe, and a contributor to numerous publications including The New Grove II, MGG, and periodicals including Tempo and Musical Opinion.

Tim Mottershead has reviewed for Tempo since 2005, having contributed articles on books, concerts, and recordings. He is also active as a reviewer of theatre. $\mathrm{He}$ is a composer, and solo pianist, performing in a wide variety of genres.

Jill Barlow is a freelance writer, music critic and pianist, based in St Albans and London area. After eight years as weekly music critic for the St Albans / Watford Observer she has now moved on to specialize more in covering contemporary music and has reviewed for Tempo since 1999. She also reviews for leading London-based newspapers and writes educational features.

Donata Premeru, musicologist, broadcaster and writer, studied at the Zagreb Academy of Music and London University. As the first musicologist at Radio Belgrade, she initiated its III programme and was one of the founders and chief editor of its weekend music programme 'Stereorama', on which she still regularly broadcasts special editions (eg cycles on Contemporary Music in the World, Women Composers, Entartete Music series, Unknown Composers of the 20th Century, Tragically Ended Careers, etc.). She has contributed to many papers and cultural reviews in the former Yugoslavia, Italy and the UK

David Matthews's Seventh Symphony was recorded for Dutton Epoch by the Bournemouth Symphony Orchestra conducted by John Carewe in July. The Dutton Epoch CD of his Second and Sixth Symphonies won the 2011 BBC Music Magazine Premiere Recording Award. He is currently composing a flute quartet for the Nash Ensemble.

Rodney Lister, composer and pianist, lives in Boston, Massachusetts, where he is on the faculty of Boston University and The New England Conservatory.

Bret Johnson is a qualified solicitor and lecturer. His main musical activities are as an organist and choir director. He contributes articles on music for several periodicals.

Martyn Becker is a pharmaceutical consultant by day and an amateur musician at all other times. He is webmaster for the Havergal Brian Society and a percussionist in the Sussex Symphony Orchestra. 
Arnold Whittall is Professor Emeritus of Musical Theory and Analysis at King's College London.

Colin Clarke studied music theory and analysis at King's College, London under Arnold Whittall and V. Kofi Agawu. He contributes to a wide variety of journals, including Fanfare and Classic Record Collector.

Bernard Hughes is a composer living in London. Recent commissions include A Medieval Bestiary, a large-scale work for the BBC Singers.

Guy Rickards is a regular contributor to The Gramophone, Tempo and International Piano and the author of Hindemith, Hartmann and Henze and Jean
Sibelius for Phaidon Press. More recently, he contributed to Landscapes of the Mind, devoted to the music and career of John McCabe and has continued to not complete a Life-and-Works study of Harold Truscott.

Clemens Gresser works as a music librarian, and is interested in indeterminate music as well as issues of 20th-century music and politics. In 2004 he completed a Ph.D. at the University of Southampton: '(Re-)Defining the relationships between composer, performer and listener: Earle Brown, John Cage, Morton Feldman and Christian Wolff'. He has published on the composers of his Ph.D., and Frederic Rzewski. 